\title{
Representation in the EU and beyond: one of a kind or not so unique after all?
}

\author{
by Matthias Vileyn
}

Antwerp Centre for Institutions and Multilevel Politics (ACIM)

Email: matthias.vileyn@uantwerpen.be

\begin{abstract}
In federal polities citizens have multiple public identities: they are addressed as members of the federal polity and as members of a sub-federal polity. Consequently, citizens are represented at the federal level through two channels of democratic representation: federal representation and sub-federal representation. Although this is a crucial element in the set-up of a federal system, the existing literature on representation hardly touches upon this and hence we introduce an approach to systematically compare these channels of representation. In this paper we conceptualize and operationalize the new concepts and apply our approach to democratic representation in 13 federal polities, including the EU, EU member states and non-EU member states. Our analysis shows that the EU has the highest degree of sub-federal representation (i.e. representation of the member states), but also shows that the EU stands not alone among federal polities. Belgium, Canada and Switzerland are clearly characterized by a high level of sub-federal representation as well, while countries such as the US and Australia are much more based upon federal representation. We also show that the variance between the countries can be understood by looking at the systemic features of the states.
\end{abstract}

Keywords: federalism; representation; democratic legitimacy; European Union all?" Federal Governance, vol. 11 no. 1, pp. 1-23. 


\section{About Federal Governance}

Federal Governance is an online graduate journal on theory and politics of federalism and multilevel governance. Its mandate is to engage the global federalism community and reach out to outstanding graduate students interested in federalism and multi-level governance. By providing a platform for graduate students to have early success in their careers, Federal Governance seeks to promote and sustain interest in federalism and multi-level governance research among graduate students. Allied with the Forum of Federations and founding partner, Institute of Intergovernmental Relations at Queen's University; Federal Governance aims to contribute to a global dialogue on federalism.

Co Chairs, Advisory Committee:

Publisher:

Managing Editor:

Associate Editors:
Rupak Chattopadhyay and Christian Leuprecht

Forum of Federations

(Rupak Chattopadhyay and Philip Gonzalez)

Maria Bertel

Eyene Okpanachi, Samir Sharma, Marc Woons, Johanna Schnabel, Arun Sagar, Angustias Hombrado.

\section{Terms of Use}

Your use of this Federal Governance article indicates your acceptance of Federal Governance's Terms and Conditions of Use, available at www.federalgovernance.ca/terms. Federal Governance's Terms and Conditions of Use provides that you may use Federal Governance content only for personal, academic and non-commercial use. Each copy of any part of this Federal Governance article must contain the same copyright notice that appears on the screen or printed page of such transmission. 


\section{INTRODUCTION}

Robert Dahl (1994) was one of the first to discuss the transformation of democracy, noticing that the ancient Greek model of direct democracy in city-states gradually evolved into the representative form of democracy that is dominant today. Although representative democracy was already a first step for states to cope with a growingly complex environment, recent evolutions forced them to develop further (see for example Hurrelmann et al. 2005; Zolo 1992; Zürn \& Leibfried 2005). On the one hand we observe a growing trend of decentralisation within states, while on the other we also see that states increasingly pool sovereignty at a higher level. Especially in federal polities these trends call for a reinterpretation of democratic institutions. In this contribution we introduce an alternative approach to study democratic legitimacy, applied to 13 federal polities, including the European Union (EU). More in particular, we present a perspective to study democratic representation in federal polities that incorporates multiple channels of representation.

Part of the input-dimension of democratic legitimacy, representation is a crucial aspect in current-day democracies, especially since there is no real alternative at hand (Lefébure 2009; Lord 2004). Most literature on democratic legitimacy of federal systems, including the EU literature, starts from traditional conceptualisations of legitimacy. For quite some time the concept of 'democratic legitimacy' has been closely associated with the distinction between input- and output-oriented legitimacy, famously put forward by Fritz Scharpf (1999). Inputoriented legitimacy refers to the ability of citizens to provide input into the decision-making process, whereas output-oriented legitimacy deals with the compatibility between the outcome of the system and its acceptance by the citizens. This framework has been revised regularly. Vivien Schmidt (2010), for instance, opened it up to the systems theory of David Easton. Combining the work of Scharpf and Easton, Schmidt adds a third dimension to the debate: throughput legitimacy, which points to the process of decision-making and includes efficiency, accountability, transparency and openness to civil society. In recent years, many authors have discussed different issues of democratic legitimacy, often also related to the EU. Some focused on the difference between input and output legitimacy (e.g. Bellamy 2010; Lord 2004; Scharpf 1999); while others studied deliberation (e.g. Eriksen \& Fossum 2011), identity and public sphere (e.g. Eriksen 2005), the contestation for political leadership (e.g. Follesdal \& Hix 2006), accountability (e.g. Papadopoulos 2010), participation and representation (e.g. Kröger \& Friedrich 2012; Marsh \& Norris 1997; Monaghan 2012), issues of congruence between voters and representatives (e.g. Casado-Asensio \& Lefkofridi 2011) or the role of nation-states in post-national democratic legitimacy (e.g. Glencross 2010).

However, while acknowledging the evolving literature, it occurs to us that constituent units are not explicitly involved in these analyses, not even when discussing the democratic legitimacy of multilevel polities. We contend that one of the most defining characteristics of federal systems is precisely the existence of constituent units. Autonomous from but at the same time cooperating with the federal level of government, constituent units bring into practice the idea of 'self-rule and shared-rule' and are consequently vital in the democratic functioning of a federal system (Burgess 2006; King 1982; Watts 1999). In federal polities citizens have multiple public identities, which entails two channels of democratic representation: they can either be addressed as citizens of the federal polity or as citizens of sub-federal entities. 'Sub-federal' refers to all constituent units of a federal polity; it covers geographically demarcated regions, cultural groups as well as all other types of collectivities that play a role in constituting the federal system. Of course we say nothing new if we say that constituent units are represented at the federal level, but the main addition of this paper is that we systematically compare the degree of sub-federal representation in a broad range of federal systems. Starting from these federal and sub-federal channels of representation, this paper therefore aims to answer two questions. How can we re-conceptualise 
representation, taking into account the somewhat neglected distinction between 'sub-federal representation' and 'federal representation'? And how can we interpret the different proportion of both channels in a set of 13 federal polities?

\section{RECONCEPTUALIZING DEMOCRATIC REPRESENTATION IN FEDERAL POLITIES}

Democratic representation features prominently in debates on democratic legitimacy in which some authors discuss the legitimacy of collectively binding decisions (e.g. Scharpf 1999) and others the legitimacy of the political system as a whole (e.g. Schmidt 2010). We put ourselves in the slipstream of Schmidt (ibid. 2010, p.9), who argues that democratic legitimacy 'relates to the extent to which institutional and interactive input politics, throughput processes and output policies are acceptable to and accepted by the citizenry, such that citizens believe that these are morally authoritative and they therefore voluntarily comply with government acts even when these go against their own interests and desires'. While studies of democratic legitimacy are valuable indeed, we take our magnifier and go one step further by focussing on democratic representation. In the typology presented by Schmidt (2010) representation is part of the input-dimension of democratic legitimacy. This dimension stipulates that polities are input legitimate once 'they reflect the 'will of the people', that is, if they can be derived from the authentic preferences of the members of the community' (Scharpf 1999, p.6). As Lord (2004) claims, this input dimension is the most crucial one in democracies. He argues that only democracies are 'open to being justified in terms of a particular configuration of rights and obligations and of procedures that secure those rights' (Lord 2004, p.13). Technocracies and authoritarian rulers may produce similar output as democracies, but this is not the case for input legitimacy. An additional motivation why we focus on input legitimacy is given by Majone (1998). He argues that input legitimacy is particularly relevant for redistributive policies, while it is somewhat less crucial for regulatory policies. Since we are especially interested in the democratic legitimacy of the political system as a whole, i.e. addressing both regulatory and redistributive policies, the input dimension gains relevance. Within this input-legitimacy a special place is reserved for representation. According to several authors there is no realistic alternative to democracy through representatives (Beichelt 2009). According to Eriksen and Fossum (2007, p.9) 'no system can accommodate the participation of all relevant stakeholders' which makes representation of particular importance.

Citizens of federal polities incorporate multiple identities and are thus represented through the federal channel as well as through the sub-federal channel. Put otherwise, in federal systems individuals are addressed as both federal and sub-federal citizens. This observation partly mirrors the on-going debate regarding the EU's democratic deficit. The EU is based on dual legitimacy, in which both citizens and states play a role (Eriksen \& Fossum 2011; Fabbrini 2007). Some authors argue that the citizen-channel should be decisive in the democratic debate (i.e. Follesdal \& Hix 2006), whereas others prefer a leading role for the states (i.e. Moravcsik 2002). The bottom line in this debate is that citizens are either addressed as European individuals or as members of the EU member-states. Extrapolating from the European case, we arrive at citizens of a federal polity and citizens of a sub-federal part of the polity. Federal representation then occurs if citizens as members of the federal polity are represented at the federal political level. Sub-federal representation, in its turn, is observed when citizens as members of the constituent units are represented at the federal political level. It is also important to add that there is a difference between sub-federal representation and indirect representation, although the two are closely related. In fact both federal and sub-federal representation can occur directly or indirectly. Sub-federal representation refers to the group that citizens are related to, whereas (in)direct representation points to the mechanism to obtain representation (the means to an end). 
Finally, it is crucial to note that federal and sub-federal representation do not exclude one another: they coexist. In any given federal polity some institutional settings can be attributed to the federal channel and others to the sub-federal channel.

Figure 1 summarizes this approach. The two arrows represent the channels of representation, which lead to the federal political level on top. Whereas federal representation is about being represented as citizen of the federal polity, sub-federal representation refers to being represented as citizen of the constituent units.

Figure 1. Channels of representation in federal polities

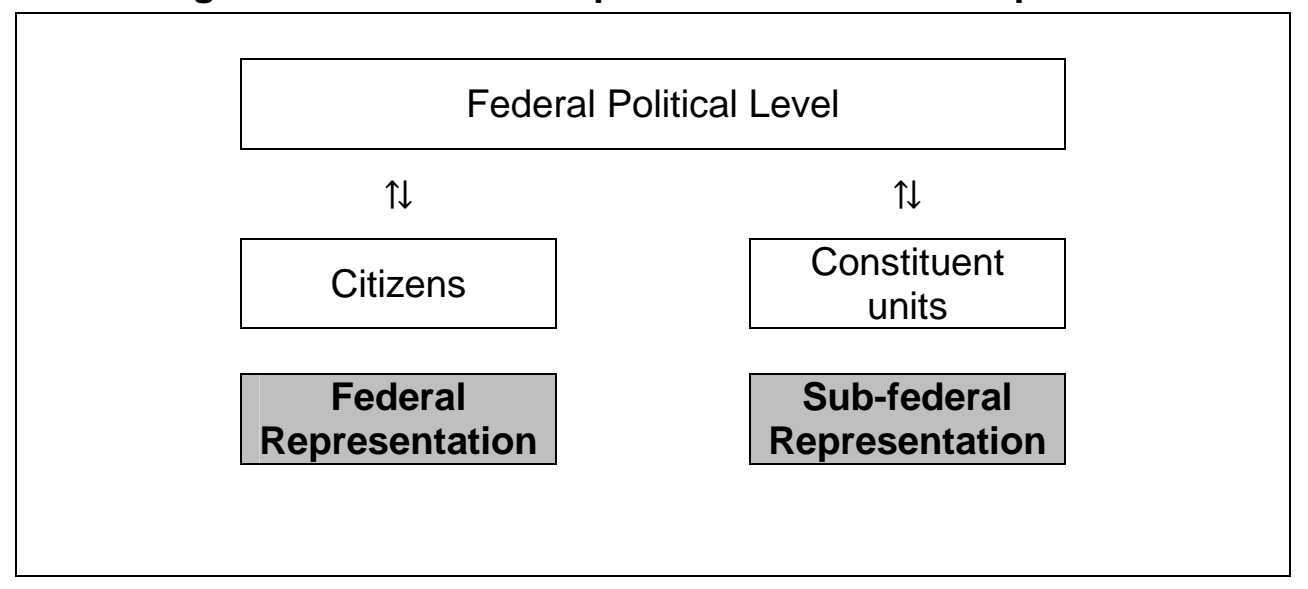

But how do we perceive representation? In politics, the notion of representation refers to the ability of citizens to be represented in relevant decision-making bodies. The better citizens are represented at the decision-making table, the higher the level of input legitimacy of a political system (Burgess 2006; Bursens 2009). In current day politics, representation is very closely associated with the 'responsible party government' model. In this model several parties present themselves to the voters with policy promises and evaluations of the past performances. In order for this model to work effectively, parties 'need to provide an alternative set of programmes on the major issues facing the country', while 'voters need to choose parties based on retrospective evaluations of their record in government, or prospective evaluations of their policy platforms'. Last but not least 'free and fair elections need to be held at regular intervals to translate votes into parliamentary seats, and seats into government' (Marsh \& Norris 1997, 153-154). This traditional interpretation of representation links the preferences of the citizens to the achievements and performances of governments. One possible approach to analyse representation is to make the distinction between elective, semi-elective and non-elective forms (Saward 2010). We focus on elective forms, i.e. on political institutions, such as parliaments and political parties. Despite the correct observation of Bardi and colleagues (2010) that parties 'have lost their capacity to act as representative agencies', parties remain crucial in democratic representation and are therefore explicitly incorporated in our analysis.

Concluding, we wish to stress that it is not our intent to evaluate democratic representation and subsequently argue why one form of representation is better than the other. Our goal is to sketch a picture of how representation in federal polities incorporates the twin notions of federal and sub-federal representation and to interpret the differences between federal polities. 


\section{MEASURING DEMOCRATIC REPRESENTATION IN FEDERAL POLITIES}

\section{Operationalisation}

In federal or compound polities it is not so easy to organize representation in a straightforward way. Representation is much more complex in federal states than it is in unitary states: 'compounded representation can therefore be defined as the interaction between principals and agents under conditions of shared rule, in which multiple agents compete for and share authority in overlapping jurisdictions and are accountable to multiple constituencies' (Brzinski, Lancaster, \& Tuschhoff 1999, 10; Tuschhoff 1999). This observation entails that we need to carefully operationalize the concept of federal and subfederal representation. How do we recognize federal and sub-federal representation when we see it? In this paragraph we present five empirical utterances of democratic representation that deal with the distinction between federal and sub-federal representation.

Analysing federal representation in representative democracies obviously includes looking at how the parliamentary system functions. As this political institution is at the heart of representative democracy, numerous ways of legitimating the polity cross its paths. The first and foremost way to obtain federal representation is the existence of free and fair elections, which is of course also a precondition for any democratic society. Relevant here is that citizens of the federal polity can directly elect those who will represent them in the federal parliamentary assembly, particularly in upper chambers of federal polities. This is not always the case though: constituent units often only indirectly compose these upper chambers. Whereas direct elections for the federal level point towards more federal representation, indirect elections give more representational power to the sub-federal level - if those are indeed elected by the constituent units.

A second indicator can be found in the role of political parties. Polity-wide parties function as intermediaries between the people and the federal level: the stronger these parties are - in comparison to non-polity-wide parties - the stronger the interests of the citizens are represented at the federal level. If non-polity-wide parties (or sub-federal parties) are dominant, however, this points towards sub-federal representation. Parties are still very much linked to representing the people and if they are focused on the level of the constituent units this has implications for (sub-) federal representation. Besides this, we also have to consider the existence of an electoral link between citizens and those who govern them at the federal level (so that the former can hold the latter electorally accountable). Members of the federal executive are often only elected by their own electoral constituency, since the borders of constituencies rarely cross borders of constituent units. But if the members of government are member of a party that all citizens in the different constituent units can vote for, some linkage remains. If this link is present, this points to federal representation. Its absence, in its turn, reflects sub-federal representation.

The third indicator is the equality of reserved seats between constituent units in federal upper chambers. By allowing each constituent unit to have a fixed proportion of the seats, subfederal authorities can have a say in federal decision-making. This is very common in all federal polities, but one difference enables a different score: in some instances the number of seats is the same for every constituent unit, whereas in others the number of seats (partly) depends on the population of the constituent units - similar to elections of the lower chamber. If all constituent units are represented equally despite differences in size and population, this leads to a higher score for sub-federal representation since this means that the constituent unit people come from is more important than the people themselves. Although this may seem a small difference it unravels a broader underlying philosophy in the federal upper chamber: a chamber to represent citizens or a chamber to represent constituent units. 
A fourth indicator is the position of the constituent units in the decision-making process. To what extent are the parliaments and governments of the constituent units involved in federal decision-making? Veto-power of the constituent units obviously leads to a higher degree of sub-federal representation if all constituent units can block legislation. The lack of vetoes or, more generally, low involvement of constituent units means the federal level has more autonomy and that the different representatives primarily represent all federal citizens. If this role is significant this leads to a higher score for sub-federal representation, whereas completely independent federal decision-making tends to lead to higher federal representation.

The fifth indicator refers to the composition of the federal government. To what extent are federal entities represented? This can range from a federal government composed of representatives of the constituent units to a less institutionalised system with quota. If the presence of the different constituent units is ensured, this means that sub-federal representation is higher, since these executives to some extent represent the interests of their constituent units, while a lack of rules regarding the composition of the federal government refers to federal representation. Table 1 summarizes the operationalisation of both channels of democratic representation.

Table 1. Operationalisation

\begin{tabular}{|l|l|}
\hline \multicolumn{1}{|c|}{ Federal representation } & \multicolumn{1}{c|}{ Sub-federal representation } \\
\hline Direct federal elections & No direct federal elections \\
Dominant polity-wide parties & Dominant non-polity-wide parties \\
No reserved seats in federal chamber & Reserved seats in federal chamber \\
Weak position of constituent units & Strong position of constituent units \\
No guaranteed seat in federal & Guaranteed seat in federal \\
government & government \\
\hline
\end{tabular}

\section{Case selection}

This paper focuses on democratic representation as a major aspect of democratic legitimacy in federal political systems and thus the cases have to be both federal and democratic. The Forum of Federations (2013) lists 27 countries as being either federal or in transition towards federalism. Only democracies will be considered, though, and thus we narrow the list down with help of Freedom House (2012), which lists countries as free, partly free or not free, depending on a score for political rights and civil liberties. We have opted to include only free countries, since comparability is one of the fundamental requirements of comparative research. In this paper the focus is on representation, which is only ensured in free democracies. Without the subject of study it would be impossible to compare the different cases. For the very same purpose - comparability - we also excluded two other federal democracies: Saint Kitts \& Nevis and Micronesia. Even though they may provide interesting insights, they are hardly comparable to our other federal polities given their small population (and matters related to this small population such as the lack of political parties). Especially if we wish to compare the EU to these systems, several problems pop up. By adding the European Union to the selected federal systems we end up with 13 cases of federal democracies: Argentina, Australia, Austria, Belgium, Brazil, Canada, the European Union, Germany, India, South Africa, Spain, Switzerland and the United States.

Why do we include the EU in this list? Hix (2005) convincingly argued why we ought to see the EU as a political system and even the idea that it is a federal political system is widely accepted in the literature. The main argument is that there is a significant difference between the concepts of federalism, federal political system and federation. Federalism refers to the broader principles, to an ideal. Federalism is a normative term, whereas 'federal political 
system' is its structure, its real-world application. The third concept 'federation', then, is one possible utterance of this federal structure (King 1982; Watts 1998; Watts 1999). Other examples of federal structures are confederations, unions, leagues, quasi-federations or constitutional regionalisation (Burgess 2006; Elazar 1987). Our starting point is that the EU is a federal political system. We follow Watts, who sees a federal political system as a system characterized by 'two (or more) levels of government thus combining elements of shared-rule through common institutions and regional self-rule for the governments of the constituent units' (Watts 1999, p.7). In a federal polity distinct identities are accepted and even accommodated (Deschouwer, 2009; Watts, 1998, 1999). This certainly holds for the EU, having shared decision-making in the Council, the Commission, etc. and self-rule in the member states.

\section{ANALYZING DEMOCRATIC REPRESENTATION IN FEDERAL POLITIES}

\section{Federal and sub-federal representation in 13 polities}

Based on country-specific and comparative literature (such as country profiles by the Forum of Federations) as well as constitutional documents, all polities were calibrated for each indicator with a value between 0 and 1 - the higher the number, the more sub-federal representation. ${ }^{1}$ For each indicator there are five categories: 0 refers to the absence of an indicator; 0,25 to a position in between leaning towards the absence of the indicator; 0,5 to a position in between; 0,75 to a position in between leaning towards the presence of the indicator; and 1 to the presence of the indicator. Let us consider first the indicator of direct federal elections. Each polity has at least one directly elected chamber (the lower house), so variance occurred through distinguishing between directly and indirectly elected second chambers (the upper house or senate). If its members were directly elected, these assemblies received a score of 0 . Some of these second chambers are indirectly elected, however, resulting in a score of 1 . In these latter cases the constituent units are responsible for deciding who is representing their interests in the second chamber. Four polities are situated in between these two extremes: Canada, India, South Africa and Switzerland.

In Canada the senators are appointed by the Governor-General on advice of the Prime Minister, which is thus neither directly elected nor indirectly elected by the constituent units (resulting in a score of 0,5 ). In India the majority of parliamentarians is indirectly elected by states and territories, but some are appointed as well (score of 0,75 ). South Africa has a directly elected first and second chamber, but also an indirectly elected 'Council of Traditional Leaders' - which is appointed by the provincial Houses of Traditional Leaders (score of 0,5 ). The Swiss constitution, finally, depicts that cantons can decide for themselves how the representatives are selected. De facto, however, all cantons have direct elections and thus the score is inclining towards direct federal elections (score of 0,25). For the measurement of the second indicator on the dominant party level, the key was to look at the extent to which polity-wide parties are dominant in the political landscape. The highest score (1) was given to polities in which this is not the case (e.g. Belgium's split party system), while the lowest score (0) was given to cases with exclusively polity-wide parties (Australia, Austria, Brazil, South Africa and the US). Lower intermediate scores $(0,25)$ were attributed to cases with some exceptions (e.g. Basque or Catalan parties in Spain), while higher intermediate scores $(0,75)$ were given to cases with significant exceptions (e.g. EU party federations).

The third indicator - equal state representation in the federal chamber - was measured using constitutional documents and comparative studies. If all constituent units have the same number of seats, regardless of their population, the polity gets the highest score. This is the case in most polities (e.g. US Senate), but there are some exceptions, most notably in 
Austria, Belgium, India and Spain. While there is no case of a purely population-based allocation of seats, these latter four cases do show that some polities incorporate a weighted form of representation for the federal second chamber. The fourth indicator looks into the presence of veto-rights of constituent units and is mostly based on Watts (2008). The presence of absolute vetoes for the constituent units yields the highest score (1), while the complete absence entail the lowest score $(0)$. In between we find absolute vetoes on only a selected number of policy fields, suspensive vetoes, joint sittings, etc. More veto-rights enable higher scores for sub-federal representation. The fifth indicator - the composition of the federal government - again stems from constitutional documents, but takes into account informal arrangements as well. If all constituent units have a guaranteed place at the table, this leads to a high score of 1. Without such formal (e.g. Belgium, EU or Switzerland) or informal (e.g. Canada) arrangements the sub-federal representation is lower (0). This is for instance the case in the US, where the president nominates and the Senate approves ministers. Of course the constituent units indirectly have a say in this through the Senate, but this does not equal guaranteed presence in the cabinet. The scores for the individual indicators and the combined overall score are presented in table 2.

This table shows very clearly that a majority of federal political systems (nine out of thirteen) obtain a score below 0,5 and are thus primarily based on the federal channel of democratic representation. These include obvious examples of monolingual, administrative federal polities such as Australia and the United States, but also less likely examples such as Spain. The latter has strong provinces in Catalonia and the Basque country, but yet has rather centralist tendencies in its institutional set-up. The cases scoring high on sub-federal representation are less surprising, however. The European Union, Belgium, Canada and Switzerland all have a multilingual and diverse society, which apparently translates into the set-up of channels of representation.

Table 2. Scores sub-federal representation

\begin{tabular}{|l|c|c|c|c|c|c|}
\hline \multirow{2}{*}{ Political system } & \multicolumn{7}{|c|}{ Indicator } & \multirow{2}{*}{$\begin{array}{c}\text { Total score sub- } \\
\text { federal representation }\end{array}$} \\
\cline { 2 - 6 } & 1 & 2 & 3 & 4 & 5 & 0,85 \\
\hline European Union & 1,00 & 0,75 & 0,75 & 0,75 & 1,00 & 0,70 \\
\hline Belgium & 1,00 & 1,00 & 0,25 & 0,25 & 1,00 & 0,65 \\
\hline Canada & 0,50 & 0,50 & 1,00 & 0,75 & 0,50 & 0,65 \\
\hline Switzerland & 0,25 & 0,25 & 0,75 & 1,00 & 1,00 & 0,45 \\
\hline Germany & 1,00 & 0,25 & 0,50 & 0,50 & 0,00 & 0,45 \\
\hline Argentina & 0,00 & 0,25 & 1,00 & 1,00 & 0,00 & 0,40 \\
\hline Brazil & 0,00 & 0,00 & 1,00 & 1,00 & 0,00 & 0,40 \\
\hline India & 0,75 & 0,75 & 0,25 & 0,25 & 0,00 & 0,40 \\
\hline United States & 0,00 & 0,00 & 1,00 & 1,00 & 0,00 & 0,35 \\
\hline South Africa & 0,50 & 0,00 & 1,00 & 0,25 & 0,00 & 0,35 \\
\hline Spain & 1,00 & 0,25 & 0,25 & 0,25 & 0,00 & 0,30 \\
\hline Austria & 1,00 & 0,00 & 0,25 & 0,25 & 0,00 & 0,25 \\
\hline Australia & 0,00 & 0,00 & 1,00 & 0,25 & 0,00 & \\
\hline
\end{tabular}

Indicator 1: Indirect federal elections ( $0=$ direct; 1 = indirect)

Indicator 2: Dominant party level $(0=$ polity-wide parties; 1 = non-polity-wide parties)

Indicator 3: Equal state representation in federal chamber $(0=$ no reserved seats; 1 = reserved seats)

Indicator 4: Veto-rights of constituent units ( $0=$ no vetoes; $1=$ vetoes)

Indicator 5: Ensured presence in the federal government $(0=$ no guaranteed seats; 1 = guaranteed seats) 


\section{Discussion}

A closer look at the table reveals that the EU obtains the highest score, which is perhaps not very surprising. It is the only polity that has a high score $(0,75$ or 1$)$ in all categories: the second chamber - the Council of Ministers - is not directly elected; the party electoral link is weak since the party federations are still very much in development; all member-states have the same number of seats in the second chamber; the member-states have relatively high veto-power; and finally each member-state has a guaranteed position in the executive (Council or Commission). The combination of those characteristics makes the EU a chief example of sub-federal representation.

Belgium is the second in the row, with a score of 0,70 . Belgium's lower scores are mostly related to the process of federal decision-making: the second chamber has varying representation specified for each unit and the constituent units have low veto-powers (which can perhaps be explained by the historically dual nature of Belgian federalism). There are remarkable features of sub-federal representation, though. The second chamber is indirectly elected; there are no nation-wide political parties; and both Flanders and Wallonia have guaranteed positions in the composition of the federal government. Overall representation in Belgium is thus more sub-federal than federal.

Closely behind Belgium we find Canada and Switzerland, with a score of 0,65 . Similar to the previous cases the majority of indicators incline towards sub-federal representation. If we first look at Canada, we see that the highest scores are observed in the allocation of reserved seats in the second chamber, with an equal representation for four regional groups of provinces. We also find an absolute veto (legally, albeit in practice not as strong) for the provinces and observe that the Governor-General appoints representatives in the second chamber. Currently the prime minister is responsible for the recommendations to the Governor-General, but some provinces have already installed electoral schemes to select senators. Although those bind neither the prime minister nor the Governor-General, this trend underlines an evolution towards the democratisation of the Canadian Senate. Other intermediate positions (neither clearly federal nor clearly sub-federal representation) are found in the dominant party system. While most parties are nation-wide, some significant ones are primarily focused on one province (e.g. Parti Québécois). Canada has the same parties at the provincial and federal level, though. Finally, the composition of government (informal agreement) yields similar, intermediate results. The Swiss, finally, have a positive score in all but one category. The second indicator (dominance of non-polity-wide parties) is relatively low, since the majority of parties are organised nation-wide - with only some parties exclusively active in a limited number of regions. An intermediate score of 0,25 is also found in the first indicator. While in theory all cantons can individually decide whether there are direct elections of the second chamber or not, in practice all have implemented direct elections. The remaining indicators are higher: full cantons all have the same number of representatives; the cantons have an absolute veto through the mediation committees; and all cantons have a guaranteed position in the executive.

While the EU, Belgium, Canada and Switzerland have a dominance of the sub-federal channel of representation, the overall majority of cases has a score lower than 0,50 (which indicates that the federal channel of representation is dominant). Next in line are Argentina and Germany, who each have a score of 0,45 . In the case of Argentina this is mainly so because of its equal state representation in the Senate and the absolute veto-power of the constituent units. In Germany it is due to a high score for the indirect elections of the Bundesrat and an intermediate score for equal state representation and veto-power. Not every Land is represented equally, but there are four categories of weighted state voting, thus partly depending on the number of inhabitants. The Länder are thus neither equal nor 
completely unequal. Regarding the veto-power there is also an intermediate score: there is a suspensive veto on federal legislation that can be overridden by a corresponding Bundestag majority, but there is also an absolute veto on any federal legislation affecting state administrative functions (2008). In Argentina and Germany the proportion between federal and sub-federal representation is thus rather balanced.

A slightly lower score is observed in Brazil, India and the United States $(0,40)$. Brazil and the US in fact obtain the same scores on all indicators: strongly sub-federal regarding equal state representation and veto-power for the constituent units, but strongly federal regarding the other three indicators. India, on the other hand, has higher scores because of indirect federal elections (238 parliamentarians are indirectly elected by states and territories; 12 are appointed), but also because of the relative dominance of regional parties. Overall, one could say that these three polities lean towards federal representation, while also acknowledging their constituent units.

South Africa and Spain follow this same trend, with a score of 0,35. The sub-federal characteristics of South Africa are situated in the equal state representation and - to a lesser extent - in the indirect elections of the Council of Traditional Leaders and some small veto rights through the combination of both a legislative and intergovernmental role of the upper chamber (Watts 2008). In Spain the situation is different, in that one indicator is clearly subfederal (being the indirect election of the Senate), while three are predominantly federal (party level, equal state representation and veto-rights) and one outspokenly federal (ensured presence in government). It is remarkable that the Spanish case has some tendency towards sub-federal representation in four out of five indicators, whilst also remaining predominantly characterised by federal representation in general.

Austria and Australia are the final two polities. Austria has an indirectly elected federal chamber, but all other indicators point towards federal representation: dominant polity-wide parties, weighted state representation (although in multiple categories), only a suspensive veto for the constituent units (Watts 2008)) and no guaranteed seats in government. The final polity, Australia, has the lowest score $(0,25)$. There are direct elections, the polity-wide parties dominate, there are limited vetoes and there are no guaranteed seats in the federal government. There is, however, equal state representation, but this is the only characteristic pointing towards sub-federal representation. Given the administrative nature of Australian federalism, this could hardly be called a big surprise.

\section{Explaining differences}

Why do some countries have higher scores than others? One way to look at this is to seek systematic patterns in the cases. There are of course several parameters to explain this. Here the focus is on more general characteristics of federal systems, namely the evolution of federalism (centripetal vs. centrifugal) and linguistic diversity (homogeneous vs. heterogeneous). In the following the paper has a brief look at those two characteristics.

\section{Direction of federalism}

While the twin notions of centrifugal and centripetal forces have become quite common in the literature on federalism, they are mentioned only scarcely in overviews of the literature. Burgess (2006) is one of the exceptions as he delves into the publications of Bryce, the first to introduce the concepts back in 1901. Put short, centripetal forces 'drew men or groups of men together into one organised community while centrifugal pressures were those that impelled men to break away and disperse' (Burgess 2006, 18). Swenden et al. $(2006,864)$ even call the question whether the 'centrifugal and bipolar logic of Belgian federalism 
triggered a dynamic that inevitably undermines the very survival of the Belgian state and nation'. More on this can be found in the literature on divided societies. Reilly (Reilly 2004, 7) sees centripetal polities as those with the focus of political competition directed at the centre - not at the extremes. Although his focus is mainly on conflicts and moderate decisionmaking with all partners, the parallel to federalism can easily be made. In the case of federalism the centre refers to the federal level, while the extremes are the constituent units. Translated into the practical function of federal polities, this means that in centripetal polities the constituent units are coming together to form a stronger federal level. In centrifugal polities the constituent units gain more power and the federal polity is falling apart (or holding together, depending on the viewpoint). Polities, and especially federal polities, are often exposed to both opposing forces, but context determines which particular tendencies dominate. A fine example of these opposing forces can be seen in the European Union (Pinder 2010). Some argue for an increasingly federalised Europe, while others want the balance of power to be situated at the level of the member-states. The institutionalisation of the European project is clearly mirroring these two opposing trends. Another utterance is found in the establishment of new states. According to Reilly $(2004,12)$ it is helpful to adopt institutions that constrain centrifugal forces, since they often affect newly created nations.

The question how the direction of federalism affects federal and sub-federal representation can be answered by two possible explanations. On the one hand one could argue that in centrifugal federalism more power is flowing to the constituent units, thus enabling options for sub-federal representation. If the constituent units are gaining importance, one can expect that citizens of these constituent units are represented as such at the federal level. On the other hand one could also argue that the institutional set-up of a polity adapts more slowly than the trends in society. If constituent units are coming together, they will most likely retain some way of being represented at the federal level since they used to be more independent. Constituent units are the building blocks of federalising polities and thus they might want assurances for proper representation.

There are thus two possible and conflicting arguments, but which one is more likely? Does the institutional set-up follow the direction of federalism or do the historical roots of the polity dominate? Additionally, it can also be argued that the direction of federalism changes in the course of history. Depending on the timing, the direction of federalism and the degree of subfederal representation might change. It is beyond the scope of this paper to take into account the timing issue, however. Further research will thus have to point out to what extent this condition is a factor, but the two options already show us the relevance of this condition: the direction of federalism can be linked to both channels of representation.

A look at the data reveals that there are five cases with centrifugal federalism (being Belgium, Brazil, Canada, India and Spain) and eight cases with centripetal federalism (Argentina, Australia, Austria, the EU, Germany, South Africa, Switzerland and the US). Of the four cases with a high score on sub-federal representation there are two centrifugal and two centripetal cases. Of the nine cases with a low score on sub-federal representation there are six centripetal and three centrifugal cases. There is certainly no obvious pattern in those results and the aforementioned argumentation may thus be plausible: the effect of the direction of federalism is not necessarily straightforward.

\section{Linguistic diversity}

Often trends and pressures in society lead to adaptations in the institutional architecture and diversity is one of the contributing factors. Two very concrete utterances of internal diversity are the presence of sub-state nationalism and linguistic diversity. 
To begin with, Keating (2001) states that there are far more nations than there are states. According to Norman $(2006,96)$, 'the basic challenge in the design of a multinational federation is to coordinate (a) the self-government aspirations of more than one national community, and (b) the rival nation-building projects by political actors in these communities, especially those in control of government institutions'. The constituent units often (but not always) coincide with those distinct national communities. In multinational federal polities the odds are that sub-federal representation will be a part of the overall setup of representation. The constituent units then represent different national communities and in order to assure the presence of all partners of the federal circumscription, the constituent units will most likely have practices accommodating their need for representation. One of the characteristics of nationalism is 'a social and political movement to achieve the goals of the nation and realize its national will' (Norman 2006, 6). Without representation this will be hard. If we turn to mono-national or territorial federal polities, this same reasoning leads to a different outcome. The citizens of the federal polity form one demos or nation and thus the differences between constituent units are primarily of an administrative nature. Therefore there is no need to address citizens as members of both the federal polity and a constituent unit. It would thus make sense if these federal polities were primarily based on the logic of federal representation rather than sub-federal representation.

Related to the issue of nationalism is linguistic diversity. Languages are often a distinct part of federal polities and thus it would be interesting to include this issue in our analysis, especially since language is often one of the reasons why federal polities became federal in the first place (cf. Mitra 2001). Of course this does not account for traditional monolingual federations like the Austria or Germany, but it is of significant importance in - for instance Belgium or Switzerland. Multiple languages in one polity often trigger different public spheres as well. It was Habermas (1991) who first developed the concept and basically it refers to the quality of discourse and the quantity of participation within a democratic polity (Calhoun 1992). Since 'a public sphere is conceived as vehicle for marshalling public opinion as a political force' (Fraser 2007, 45), it is often considered as an essential prerequisite for the democratic legitimacy of traditional nation-states (Sinardet 2011). An intriguing case is Switzerland (Dardanelli 2010). Cantonal identities are weakening, while more homogenous language communities are being formed. These are increasingly becoming the dominant spaces for public debate. Dardanelli (2010) even warns that domestic circumstances ${ }^{2}$ support this trend and put pressure on the institutional architecture of Swiss federalism, perhaps even leading to greater politicisation of the language cleavage.

With support from the literature on federalism, nationalism and public spheres, the claim can thus be made that internal diversity - consisting of sub-state nationalism and multilingual features - in a given federal polity will coincide with sub-federal representation.

To determine whether a political system is diverse this paper uses two parameters: the number of dominant languages and the presence of regional nationalism. Thus there are four categories: polities with one dominant language without regional nationalism; polities with limited regional nationalism or a limited number of additional languages; polities leaning towards more regional nationalism and/or a number of additional languages; and finally polities with multiple languages and regional nationalism. The categorisation is based on country-specific literature, including country profiles of the Forum of Federations (cf. annex 2).

If we look at the data it occurs that 7 of the 13 cases are rather heterogeneous: Belgium, Canada, the EU, India, South Africa, Spain and Switzerland. If we compare this sample with the cases with a high score on sub-federal representation it shows that the four cases with high sub-federal representation are all diverse: Belgium, Canada, the EU and Switzerland all 
have multiple languages and varying degrees of regional nationalism. Of the nine cases with lower sub-federal representation only three have high sub-federal representation.

\section{CONCLUSION}

Representation is a crucial dimension of current day democracies and the way this is organised tells us a lot about the democratic legitimacy of any given polity. The aim of this contribution was to develop an alternative approach to study democratic representation in federal polities in a systematic way. In legitimating the federal level, citizens of federal polities are addressed as members of the federal polity and as members of one of the sub-federal polities. We introduced the study of the two related channels of representation, labelling them federal and sub-federal representation respectively. By operationalizing these concepts we showed how they could be measured, using five key indicators: direct or indirect federal elections (1), dominant (non-) polity-wide political parties (2), (no) reserved seats in the federal chamber (3), strong or weak vetoes in the decision-making process (4) and finally (no) guaranteed seats in the federal executive (5). The combination of those five features helps us understand to what extent citizens are represented at the federal level as either purely federal citizens or as citizens of both the federal polity and their respective constituent units. Subsequently our analysis showed that the argument is empirically viable. That subfederal representation is strongly institutionalised in the EU is perhaps not very surprising, but our analysis also showed that this approach holds for other federal polities. Belgium, Canada and Switzerland all obtain scores inclining towards sub-federal representation. This means that in these polities citizens are also considered to be multi-dimensional: they are citizens of the federal polity, but also citizens of their respective constituent units. Thus the citizens are represented in multiple ways, mirroring the broader institutional set-up of federal political systems, which consists of (at least) two levels of government.

A look at the societal basis of these polities is meaningful as well. While it is beyond the scope of this paper to systematically analyse differences between cases of federal and subfederal representation, a brief glance shows that all cases with a high score are characterised by a diverse society. All of them have multiple languages and some also encounter nationalist tendencies within their polity. Intuitively it therefore feels right to observe these cases at the top of our list. Misfits in this regard are India and Spain. At first glance Spain is expected to have a high score, given its multiple languages, quests for autonomy of the states and its centrifugal federalism. On the other hand, it is equally true that the Spanish case has long been characterised by contrasting views on what the 'nation' and the 'states' are (Keating \& Wilson 2009). Despite this, however, it also noted that Spain only got the lowest score on one indicator, while all others indicators at least show some inclination towards sub-federal representation. A look at the direction of federalism showed a less clear picture. Whether a federal system is centrifugal or centripetal does not seem to have a relationship with the degree of sub-federal representation.

Concluding, our analysis shows that the distinction between federal and sub-federal representation is empirically viable. The discussion has shown that we can interpret the outcome by going back to key characteristics of the federal systems themselves. Clearly, this raises new questions that need to be addressed in future work: we need to formulate hypotheses pointing to the features of the federal polities which can explain the balance between federal and sub-federal representation and to the mechanism at play. These questions remain to be resolved. So far, this contribution has shown the relevance of the conceptualisation and operationalisation of double channel of representation for the empirical analysis of federal polities, highlighting and interpreting the similarities and differences among them. 


\section{REFERENCES}

Bardi, L. et al., 2010. How to Create a Transnational Party System, Florence: European Union Democracy Observatory.

Beichelt, T., 2009. Delegation to the EU: Participation versus Efficiency in German EU-policy. In In Search of Legitimacy. Policy Making in Europe and the Challenge of Complexity. Opladen: Barbara Budrich Publishers, pp. 151-164.

Bellamy, R., 2010. Democracy without democracy? Can the EU's democratic "outputs" be separated from the democratic "inputs" provided by competitive parties and majority rule? Journal of European Public Policy, 17(1), pp.2 - 19.

Brzinski, J.B., Lancaster, T.D. \& Tuschhoff, C., 1999. Federalism and Compounded Representation: Key Concepts and Project Overview. Publius: The Journal of Federalism, 29, pp.1-17.

Burgess, M., 2006. Comparative Federalism. Theory and practice, London \& New York: Routledge.

Bursens, P., 2009. The Legitimacy of EU Decision-Making: Theory and Practice of the Open Method of Co-ordination and the European Employment Strategy. In In Search of Legitimacy. Policy Making in Europe and the Challenge of Complexity. Opladen: Barbara Budrich Publishers.

Casado-Asensio, J. \& Lefkofridi, Z., 2011. Representation in the European Union: Congruence Between Citizens and Elites in the European Parliament's Two-Level Setting. Perspectives on European Politics and Society, 12(2), pp.161-179.

Dahl, R.A., 1994. A Democratic Dilemma: System Effectiveness versus Citizen Participation. Political Science Quarterly, 109(1), pp.23-34.

Elazar, D.J., 1987. Exploring Federalism, Tuscaloosa: The University of Alabama Press.

Eriksen, E.O., 2005. An Emerging European Public Sphere. European Journal of Social Theory, 8(3), pp.341-363.

Eriksen, E.O. \& Fossum, J.E., 2007. Europe in transformation: How to reconstitute democracy? RECON Online Working Paper 2007/01.

Eriksen, E.O. \& Fossum, J.E., 2011. Representation Through Deliberation. The European Case. RECON Online Working Paper, 14.

Fabbrini, S., 2007. Compound Democracies. Why the United States and Europe Are Becoming Similar, New York: Oxford University Press.

Follesdal, A. \& Hix, S., 2006. Why there is a democratic deficit in the EU: A response to Majone and Moravcsik. Jcms-Journal of Common Market Studies, 44(3), pp.533-562.

Forum of Federations, 2013. Federalism by Country. Available at: http://www.forumfed.org/en/federalism/by_country/index.php. 
Freedom House, 2012. Freedom in the World 2012: The Arab Uprisings and their Global Repercussions, www.freedomhouse.org: Freedom House.

Glencross, A., 2010. A Post-National EU? The Problem of Legitimising the EU without the Nation and National Representation. Political Studies.

Hix, S., 2005. The Political System of the European Union Second edition., Basingstoke: Palgrave Macmillan.

Hurrelmann, A. et al., 2005. Is there a legitimation crisis of the nation state? In Transformations of the State? Cambridge: Cambridge University Press, pp. 119-138.

Keating, M. \& Wilson, A., 2009. Renegotiating the State of Autonomies: Statute Reform and Multi-level Politics in Spain. West European Politics, 32(3), pp.536-558.

King, P., 1982. Federalism and Federation, Baltimore: The Johns Hopkins University Press.

Kröger, S. \& Friedrich, D. eds., 2012. The Challenge of Democratic Representation in the European Union, Basingstoke: Palgrave Macmillan.

Lefébure, P., 2009. Citizens' Expectations: Is What Matters only What Works? In In Search of Legitimacy. Policy Making in Europe and the Challenge of Complexity. Opladen: Barbara Budrich Publishers, pp. 73-92.

Lord, C., 2004. A Democratic Audit of the European Union, Basingstoke: Palgrave Macmillan.

Majone, G., 1998. Europe's "Democratic Deficit”: The Question of Standards. European Law Journal, 4(1), pp.5-28.

Marsh, M. \& Norris, P., 1997. Political representation in the European Parliament. European Journal of Political Research, 32, pp.153-164.

Monaghan, E., 2012. Assessing Participation and Democracy in the EU: The Case of the European Citizens' Initiative. Perspectives on European Politics and Society, 13(3), pp.285298.

Moravcsik, A., 2002. In defence of the "democratic deficit": Reassessing legitimacy in the European Union. Journal of Common Market Studies, 40(4), pp.603-624.

Papadopoulos, Y., 2010. Accountability and Multi-level Governance: More Accountability, Less Democracy? West European Politics, 33(5), pp.1030-1049.

Saward, M., 2010. The Representative Claim, Oxford: Oxford University Press.

Scharpf, F.W., 1999. Governing in Europe: Effective and Democratic?, Oxford: Oxford University Press.

Schmidt, V., 2010. Democracy and Legitimacy in the European Union Revisited. Input, Output and Throughput. KFG Working Paper Series, 21.

Tuschhoff, C., 1999. The compounding effect: The impact of federalism on the concept of 
representation. West European Politics, 22(2), pp.16-33.

Watts, R.L., 1999. Comparing Federal Systems, Kingston, Ont.: McGill-Queen's University Press.

Watts, R.L., 2008. Federal Second Chambers Compared. Institute of Intergovernmental Relations Working Papers, 2, p.14.

Watts, R.L., 1998. Federalism, Federal Political Systems, and Federations. Annual Review of Political Science, 1, pp.117-137.

Zolo, D., 1992. Democracy and Complexity. A Realist Approach, Cambridge: Polity Press.

Zürn, M. \& Leibfried, S., 2005. Reconfiguring the national constellation. In Transformations of the State? Cambridge: Cambridge University Press, pp. 1-36. 
6. Annex 1: Indicators sub-federal representation

ANNEX

\begin{tabular}{|c|c|c|c|c|c|}
\hline Federal polity & Indicator 1 & 2 & 3 & 4 & 5 \\
\hline Argentina & Directly elected & $\begin{array}{l}\text { Dominant state-wide parties, } \\
\text { but important role for } \\
\text { provincial party leadership }\end{array}$ & Equal state representation & $\begin{array}{l}\text { Limited role and no real } \\
\text { veto }\end{array}$ & No \\
\hline Australia & Directly elected & Dominant state-wide parties & Equal state representation & $\begin{array}{l}\text { Limited role, deadlock } \\
\text { resolved by double } \\
\text { dissolution and then joint } \\
\text { sitting }\end{array}$ & No \\
\hline Austria & $\begin{array}{l}\text { Indirectly elected by } \\
\text { state parliaments }\end{array}$ & Dominant state-wide parties & $\begin{array}{l}\text { Weighted state } \\
\text { representation: multiple } \\
\text { categories }\end{array}$ & $\begin{array}{l}\text { Limited: more } \\
\text { administrative federalism, } \\
\text { but suspensive veto }\end{array}$ & No \\
\hline Belgium & $\begin{array}{l}\text { Indirectly by state } \\
\text { parliaments }\end{array}$ & Only non-polity-wide parties & $\begin{array}{l}\text { Majority of regional } \\
\text { representatives, weighted }\end{array}$ & $\begin{array}{l}\text { Limited role, but equal } \\
\text { powers for both chambers }\end{array}$ & $\begin{array}{l}\text { Yes, language } \\
\text { groups equally } \\
\text { represented }\end{array}$ \\
\hline Brazil & Directly elected & Dominant state-wide parties & Equal state representation & $\begin{array}{l}\text { Limited, more about } \\
\text { improving democracy than } \\
\text { about power. No real veto. }\end{array}$ & No \\
\hline Canada & $\begin{array}{l}\text { Appointed by } \\
\text { Governor-General on } \\
\text { advice of Prime } \\
\text { Minister }\end{array}$ & $\begin{array}{l}\text { Combination of federal and } \\
\text { provincial parties that are } \\
\text { loosely connected }\end{array}$ & $\begin{array}{l}\text { Equal 'regional' } \\
\text { representation }\end{array}$ & $\begin{array}{l}\text { Weakly institutionalised, } \\
\text { but executive federalism. } \\
\text { Absolute veto only legally, } \\
\text { but not in practice. }\end{array}$ & $\begin{array}{l}\text { Yes, albeit } \\
\text { informally }\end{array}$ \\
\hline EU & $\begin{array}{l}\text { Indirectly elected by } \\
\text { member-states }\end{array}$ & $\begin{array}{l}\text { Party federations not yet fully } \\
\text { developed }\end{array}$ & $\begin{array}{l}\text { Equal state representation } \\
\text { in Council and CoM }\end{array}$ & $\begin{array}{l}\text { Big role in Council, weaker } \\
\text { role of national } \\
\text { parliaments. Mostly QMV, } \\
\text { but seek consensus. }\end{array}$ & Yes \\
\hline Germany & $\begin{array}{l}\text { Indirectly elected by } \\
\text { state parliaments }\end{array}$ & $\begin{array}{l}\text { Dominant state-wide parties } \\
\text { (exception of CSU) }\end{array}$ & $\begin{array}{l}\text { Weighted state voting: } \\
\text { four categories }\end{array}$ & $\begin{array}{l}\text { Increasing role for } \\
\text { Bundesrat, but Länder } \\
\text { more administrative. } \\
\text { Absolute or suspensive } \\
\text { veto, mediation } \\
\text { committees. }\end{array}$ & No \\
\hline
\end{tabular}




\begin{tabular}{|c|c|c|c|c|c|}
\hline India & $\begin{array}{l}\text { Indirectly elected by } \\
\text { states and territories } \\
\text { (238), appointed (12) }\end{array}$ & $\begin{array}{l}\text { Dominance of regional } \\
\text { parties, but also some } \\
\text { federal }\end{array}$ & $\begin{array}{l}\text { Weighted state } \\
\text { representation: multiple } \\
\text { categories }\end{array}$ & $\begin{array}{l}\text { Increasing role, but still } \\
\text { limited. Deadlock resolved } \\
\text { by joint sitting, brief } \\
\text { suspensive veto for } \\
\text { money bills. }\end{array}$ & No \\
\hline South Africa & $\begin{array}{l}\text { Both chambers } \\
\text { directly elected, but } \\
\text { Council of Traditional } \\
\text { Leaders is appointed }\end{array}$ & Dominant state-wide parties & Equal state representation & $\begin{array}{l}\text { Both legislative and } \\
\text { intergovernmental role for } \\
\text { upper chamber. No real } \\
\text { veto. }\end{array}$ & No \\
\hline Spain & $\begin{array}{l}\text { Indirectly elected by } \\
\text { provinces, } \\
\text { assemblies of } \\
\text { Autonomous } \\
\text { Communities/Regions }\end{array}$ & $\begin{array}{l}\text { Dominant state-wide parties, } \\
\text { but some strong regional } \\
\text { parties as well }\end{array}$ & $\begin{array}{l}\text { Minority of regional } \\
\text { representatives }\end{array}$ & $\begin{array}{l}\text { Limited role, but } \\
\text { suspensive veto: time limit } \\
\text { of two months. }\end{array}$ & No \\
\hline Switzerland & Depends on Cantons & $\begin{array}{l}\text { Dominant state-wide parties, } \\
\text { but also some regional ones }\end{array}$ & $\begin{array}{l}\text { Two categories of } \\
\text { cantonal representation }\end{array}$ & $\begin{array}{l}\text { Sometimes crucial, } \\
\text { sometimes only } \\
\text { administrative. Absolute } \\
\text { veto with mediation } \\
\text { committees. }\end{array}$ & $\begin{array}{l}\text { Language and } \\
\text { geographical } \\
\text { must be } \\
\text { represented }\end{array}$ \\
\hline United States & Directly elected & Dominant state-wide parties & Equal state representation & $\begin{array}{l}\text { Limited: coercive } \\
\text { federalism, but absolute } \\
\text { veto with mediation } \\
\text { committees. }\end{array}$ & No \\
\hline
\end{tabular}

Indicator 1: No direct elections of the federal upper chamber

Indicator 2: Dominance of non-polity-wide political parties

Indicator 3: Reserved seats in federal upper chamber

Indicator 4: Involvement of constituent units in federal decision-making

Indicator 5: Guaranteed position of constituent units in the composition of the executive 


\section{Annex 2: Sources data-collection}

Argentina. "Constitution of the Argentine Nation."

[2] Arora, Balveer. 2010. "Governing Federal India: Political Institutions for a Diverse Society and a Resurgent Economy." Revue AGIR 44(Special Issue on "La Renaissance de I"Inde'): 23-32.

[3] Austria. "Federal Constitutional Law Austria."

[4] Bakvis, Herman, and Grace Skogstad. 2008. Canadian Federalism: Performance, Effectiveness, and Legitimacy. Oxford: Oxford University Press.

[5] Ballendorf, Dirk Anthony. 2005. "The Federated States of Micronesia." In Handbook of Federal Countries, Forum of Federations, p. 215-226.

[6] Cameron, David R. 2005. "Canada." In Handbook of Federal Countries, Forum of Federations, p. 106-120.

[7] Cammisa, Anne Marie. 1995. Governments as Interest Groups. Intergovernmental Lobbyng and the Federal System. London: Praeger.

[8] Church, Clive, and Paolo Dardanelli. 2005. "The Dynamics of Confederalism and Federalism: Comparing Switzerland and the EU." Regional and Federal Studies 15(2): 163 - 185.

[9] Cortes Generales. "Spanish Constitution."

[10] Dardanelli, Paolo. 2010. "Federal democracy in Switzerland." In Federal Democracies, eds. Michael Burgess and Alain-G. Gagnon. London \& New York: Routledge.

[11] Delpérée, Francis. 2006. "The Belgian Senate." In A World of Second Chambers. Handbook for constitutional studies on bicameralism, Centre for Studies on Federalism, eds. Jörg Luther, Paolo Passaglia, and Rolando Tarchi. Milano: Giuffrè Editore.

[12] Deschouwer, Kris. 2009. The Politics of Belgium. Governing a Divided Society. Basingstoke: Palgrave Macmillan.

[13] Dourado, Daniel de Araujo, and Paulo Eduardo Mangeon Elias. 2011. "Regionalization and political dynamics of Brazilian health federalism." Revista de Saúde Pública 45(1): 204-211.

[14] Erk, Jan. 2004. "Austria: A Federation Without Federalism." Publius: The Journal of Federalism 34(1): 1-20.

[15] European Union. 2007. "Treaty of Lisbon (Consolidated version)." 
[16] Fabre, Elodie. 2009. "Belgian federalism in a comparative perspective." VIVES discussion paper 5.

[17] Federal Research Division. 2004. "Country Profile: India."

[18] Fitzmaurice, John. 1996. The Politics of Belgium. A Unique Federalism. London: Hurst \& Company.

[19] German Federal Ministry of Justice. "Basic Law for the Federal Republic of Germany."

[20] Government of India Ministry of Law and Justice. 2007. "The Constitution of India."

[21] Griffiths, Ann L. 2005. "St. Kitts and Nevis (Federation of St. Kitts and Nevis)." In Handbook of Federal Countries, Forum of Federations, p. 280-294.

[22] Harty, Siobhán. 2005. "Spain (Kingdom of Spain)." In Handbook of Federal Countries, Forum of Federations, p. 324-341.

[23] Hix, Simon, and Bjorn Hoyland. 2011. The Political System of the European Union. Third Edition. Basingstoke: Palgrave Macmillan.

[24] Hrbek, Rudolf. 2005. "Germany (Federal Republic of Germany)." In Handbook of Federal Countries, Forum of Federations, p. 149-164.

[25] Kincaid, John, and Richard L. Cole. 2010. "Citizen Attitudes Toward Issues of Federalism in Canada, Mexico, and the United States." Publius: The Journal of Federalism 41(1): 53-75.

[26] Kinzo, Maria D'Alva Gil. 1993. Brazil, the Challenges of the 1990s. British Academic Press.

[27] Legal Department of the Belgian House of Representatives. 2009. "The Belgian Constitution."

[28] Linder, Wolf. 2010. Swiss Democracy. Possible Solutions to Conflict in Multicultural Societies. 3rd ed. Basingstoke: Palgrave Macmillan.

[29] Marbach, Joseph R., and J. Wesley Leckrone. 2002. "Intergovernmental Lobbying for the Passage of TEA-21." Publius: The Journal of Federalism 32(1): 45-64.

[30] Mathew, George. 2005. "India (Republic of India)." In Handbook of Federal Countries, Forum of Federations, p. 165-182.

[31] Mendes Ferreira Costa, Valeriano. 2005. "Brazil (Federative Republic of Brazil)." In Handbook of Federal Countries, Forum of Federations, p. 90-105. 
[32] Moon, Jeremy, and Campbell Sharman, eds. 2003. Australian Politics and Government. The Commonwealth, the States and the Territories. Cambridge: Cambridge University Press.

[33] Office of Legislative Drafting. 2003. "Commonwealth of Australia Constitution Act (The Constitution)."

[34] Patroni, Viviana. 2005. "Argentina." In Handbook of Federal Countries, Forum of Federations, p. 16-30.

[35] Saunders, Cheryl. 2005. "Australia (Commonwealth of Australia)." In Handbook of Federal Countries, Forum of Federations, p. 31-44.

[36] Schram, Sanford F. 2005. "United States of America." In Handbook of Federal Countries, Forum of Federations, p. 372-391.

[37] Simeon, Richard, and Amy Nugent. 2008. "Parliamentary Canada and Intergovernmental Canada: Exploring the Tensions." In Canadian Federalism. Performance, Effectiveness, and Legitimacy, Oxford: Oxford University Press, p. 89-111.

[38] Singh, Anusha. 2010. "Cooperative Federalism in India." Legal Service India. http://www.legalserviceindia.com/article/l441-Cooperative-Federalsim-InIndia.html.

[39] Singh, Mahendra P., and Douglas V. Verney. 2003. "Challenges to India's Centralized Parliamentary Federalism." Publius: The Journal of Federalism 33(4): 1-20.

[40] South Africa. 2009. "Constitutional Law. Constitution of the Republic of South Africa."

[41] Stauffer, Thomas, Nicole Töpperwien, and Urs Thalmann-Torres. 205AD. "Switzerland (Swiss Confederation)." In Handbook of Federal Countries, Forum of Federations, p. 342-356.

[42] Sturm, Roland. 2005. "Austria (Federal Republic of Austria)." In Handbook of Federal Countries, Forum of Federations, p. 45-57.

[43] Swenden, Wilfried, Marleen Brans, and Lieven De Winter. 2006. "The politics of Belgium: Institutions and policy under bipolar and centrifugal federalism." West European Politics 29(5): 863-873.

[44] Swiss Confederation. 2011. "Federal Constitution of the Swiss Confederation."

[45] United States. "The Constitution of the United States." 
[46] Watts, Ronald L. 1999. Comparing Federal Systems. Kingston, Ont:: McGill-Queen's University Press.

[47] 2008. "Federal Second Chambers Compared." Institute of Intergovernmental Relations Working Papers 2: 14.

[48] Van der Westhuizen, Janis. 2005. "South Africa (Republic of South Africa)." In Handbook of Federal Countries, Forum of Federations, p. 309-323.

[49] Williams, John M., and Clement Macintyre. 2006. "Commonwealth of Australia." In Distribution of Powers and Responsibilities in Federal Countries, A Global Dialogue on Federalism, eds. Akhtar Majeed, Ronald L. Watts, and Douglas M. Brown. Montreal \& Kingston: McGill-Queen's University Press, p. 833.

[50] De Winter, Lieven. 1998. "Parliament and Government in Belgium: Prisoners of Partitocracy." In Parliaments and Governments in Western Europe, Parliaments in Contemporary Western Europe, London \& Portland: Frank Cass.

\footnotetext{
${ }^{1}$ A list of sources and motivation for scores is presented in the annex.

${ }^{2} \mathrm{He}$ is referring to the on-going concentration in printed media, making it harder for newspapers with a strong cantonal identity to stay put. A second trend is the growing role for television and other media, which are mainly organised on a linguistic basis.
} 